\title{
Study on the Influence Factors of Interest Rate Liberalization on Net Interest Margin of Chinese Commercial Banks
}

\author{
Sicong Lin*
}

Zhejiang University of Finance \& Economics Dongfang College, Haining 314400, Zhejiang province, China. E-mail: 820895239@qq.com

\begin{abstract}
Interest margin income is the main business and profit source of commercial banks. With the promotion of interest rate liberalization, net interest margin can measure the operation and management level of a bank to some extent. Interest rate liberalization has a great impact on the development of China's commercial banks. In order to study and deal with this situation, this paper analyzes the opportunities and challenges brought by interest rate liberalization to china's commercial banks, and puts forward relevant suggestions for china's commercial banks on how to effectively utilize the development opportunities and actively deal with the challenges.
\end{abstract}

Keywords: Interest Rate Liberalization; Commercial Bank; Net Interest Margin

\section{Introduction}

Rapid development of economy in our country is marching to the direction of the economy. At the same time, the reform of market economy in our country has never stopped, and the highlight is the interest rate marketization reform. This paper mainly studies the marketization of interest rate on Chinese commercial banks to explore the influence of net interest margin. Although at present many literature illustrate the influence of interest rate marketization of commercial banks, only a small number of commercial banks under the net interest margin and in the reform of commercial banks face opportunities and challenges. The development of commercial banks is related to the trend of China's economy. In order to achieve the prosperity and development of commercial banks, it is necessary to conduct in-depth research and discussion on the impact of interest rate liberalization on the net interest margin of Chinese commercial banks ${ }^{[1]}$. Therefore, this paper, starting from the micro angle of net interest margin, makes appropriate strategies for commercial banks to make full use of opportunities and respond to challenges, and provides strategic suggestions for the development of commercial banks in China.

Influence factors of interest rate liberalization on net interest margin of Chinese commercial banks

Under the control of long-term interest rate in China, there is little room for independent adjustment of deposit and loan interest rate of banks.

With the emergence of interest rate liberalization, it has played a great advantage in the financial market.

Interest rate liberalization means that the direct control of the central bank is transferred to financial institutions, so that financial institutions and the invisible hand can conduct self-regulation, while the central bank plays a supervisory and auxiliary role ${ }^{[2]}$.

With the advancement of marketization of interest rate, the benchmark spreads gradually narrows in a smooth

Copyright (C) 2021 Sicong Lin

doi: $10.18686 /$ fm.v6i1.3275

This is an open-access article distributed under the terms of the Creative Commons Attribution Non-Commercial License

(http://creativecommons.org/licenses/by-nc/4.0/), which permits unrestricted non-commercial use, distribution, and reproduction in any medium,

provided the original work is properly cited. 
trend, which make more intense competition between commercial banks, and the required product pricing power is even more important. At the same time, because spreads narrowed, which made the traditional banking business model doesn't get better development: they have to make strategic transformation and innovation.

Moreover, the interest rate spread of commercial banks is bound to be affected by various factors. I will analyze it from three perspectives as follows:

(1) Risk aversion: the greater the risk aversion of the bank, the greater the risk premium and the larger the net interest margin, which is also a way for the bank to avoid risks.

(2) Transaction scale: the larger the asset scale is, the larger the transaction scale will be, and the scale effect will be generated. Banks will have stronger pricing power in the market competition, so as to obtain greater interest spread income ${ }^{[3]}$.

Moreover, when other conditions are fixed, the larger the loss it faces, the larger the net interest margin it needs to make up for the possible loss.

(3) Credit risk: it describes the loan business of a bank. When the lender fails to repay the loan due, the bank will assume default risk, which is the main risk faced by the bank.

Therefore, banks need wide spreads to cover their potential losses.

\section{Opportunities and challenges of interest rate liberalization to Chinese commercial banks}

\subsection{Opportunities brought by interest rate liberalization to Chinese commercial banks}

\subsubsection{Promoting financial reform and innovation}

China's banking industry relies too much on interest rate spread income, Interest rate liberalization will change the traditional profit model, force banks to innovate and reform constantly, breed a variety of financial products and develop toward diversification. Interest rate liberalization provides development space for financial derivatives, such as options and forward contracts ${ }^{[4]}$. In the face of the large income gap among different regions in China, commercial banks need to innovate financial products to realize the demand for maintaining and increasing the value of financial assets by diversifying risks, which enriches the traditional business model and promotes the improvement of the financial market.

\subsubsection{Promoting strategic transformation}

Interest rate marketization has large impact on advancing the traditional commercial bank intermediary business have a larger impact, because traditional middle business is an important source of income. To promote commercial bank's strategic transformation, it not only depends on the traditional business, but also can establish diversified mode of operation, which can both spread risk and improve its competitiveness, because traditional middle business is an important source of income. Moreover, I believe that the internationalization of RMB is a catalyst to promote the strategic transformation of commercial banks. Chinese commercial banks can obtain intermediate business income by providing brokerage services and international settlement of RMB. In addition, commercial banks can make full use of the time difference between home and abroad, to make full use of the short stay time of funds and make full preparations for their transformation and upgrading ${ }^{[5]}$.

\subsubsection{Expand operational autonomy}

After interest rate liberalization, the central bank does not have direct jurisdiction over the interest rate, but only controls the benchmark interest rate, so that commercial banks can fully consider their own operating costs, business objectives, degree of risk aversion and other factors to adjust the appropriate interest rate ${ }^{[6]}$. Under the regulated interest rate, all commercial banks follow the mean square rule. After the interest rate liberalization, commercial banks will determine the loan interest rate according to the risk degree of customers. For customers with high risk tolerance, they can set a higher interest rate to make up for the risks they bear, so as to make personalized decisions according to different people. Banks optimize the structure of assets and liabilities through reasonable prediction of market interest rates. Different banks take different measures in the face of the same situation, which also provides a variety of innovative ideas 
for the development of the market.

\subsection{Challenges to China's commercial banks from interest rate liberalization}

\subsubsection{Intensify bank competition and impact on business model (put forward higher require- ments on the ability of interest rate pricing)}

After interest rate liberalization, the independent pricing of deposit interest rate and loan interest rate will intensify the competition among banks, and the fierce competition will increase the cost of banks. Traditional management mode, the commercial bank's main business is in the table. The marketization of interest rate spreads narrowed, bank interest rates, small and medium-sized commercial banks will be hit by the traditional business model. The advantage of independent pricing and price competition bring disadvantage phase offset, price competition between banks will make abnormal rise in interest rates on deposits, and loans interest rates have been low. If they want to compete for more market shares, they have to adjust their business model, which is also a challenge for China's commercial banks to transform and upgrade. But they can improve their comprehensive strength, risk resistance ability and innovation and development ability ${ }^{[6]}$.

\subsubsection{Increase credit risk (adverse selection of interest rate leads to credit risk)}

Market has blindness. When the bank profit is lower than that of the initial forecast too much, bank managers and decision makers make up for the loss and maintain current earnings of the previous period, which is likely to buy blindly following and high-yield investment products. In the process of the pursuit of high yield, banks in order to improve the lending rate, they must be considered high-risk projects, and low credit lenders to get big money in a short period of time and agreed to the requirements of higher interest rates, which increases the credit risk of commercial banks. On the contrary, creditworthy borrowers with low risk returns will be hit, leading to adverse interest rate selection risk. And if the loan amount and risk are too large, it will cause a bubble economy and affect the whole economy ${ }^{[7]}$. From various perspectives, interest rate liberalization will increase credit risks to varying degrees. Banks need to find the appropriate interest rate setting value under the circumstance of increasing risks, and do not blindly chase after it.

\section{Countermeasure of commercial bank}

\subsection{Diversify business}

The interest rate liberalization is bound to narrow the spread between deposits and loans of banks, which is extremely unfavorable to banks whose main business under the traditional business model is the income from the spread between deposits and loans. In order to seek breakthroughs and achievements in this respect, we have to change the original dependence on deposit and loan spreads ${ }^{[8]}$. For example, we should strengthen marketing efforts and expand customer groups and financial fields and expand diversified operation and stimulate the vitality of the market. Increasing the support to local enterprises is not only conducive to the development of local economy, but also can be based in many banks and get the trust and support of local people in the long run. And in the mainstream direction, we can integrate the thinking of "internet + " into the business philosophy of banks ${ }^{[9]}$. The internet is an innovation point that the country and even the whole world pay attention to. On the road of diversified operation, the original focus will be affected, so it is necessary to establish a sound business model and strategic system.

\subsection{Improve your pricing power}

The pricing of deposits and loans is the top priority of commercial banks' products. With the promotion of interest rate liberalization, the rights of independent pricing of China's commercial banks are expanded, and the degree of liberalization is deepened. Diversified operation can spread the operating risks of banks to a certain extent, but as the main business of deposit and loan, it must be improved to improve the pricing ability of banks ${ }^{[10]}$. If the deposit pricing is too low or the loan pricing is too high, it will lead to customer outflow and market share reduction; otherwise, the profit will be reduced. Therefore, we can fully study the deposit and loan products on the market, comprehensively consider the factors such as product profit and risk compensation, establish our own price research system and pricing sys- 
tem and promote it in all aspects according to different people. At the same time, we recruit professional pricing talents to cultivate a team that can timely and accurately reflect the market fluctuations and adjust the current strategic deployment.

\section{Conclusion and suggestion}

Commercial banks must clarify that the higher the debt is, the greater the value is. They must first discard the past concept of "debt first" before they can carry out operational structure, strategic transformation and reform. Commercial banks should also make full use of the internet, cloud computing, big data and other technologies to assist their own development, integrate financial innovation with technology, strengthen their own management level and standards and establish credibility, to better serve the people to provide indicators, to lay the cornerstone for entering the international market.

The above analysis shows that interest rate liberalization brings opportunities to the development of China's commercial banks and will promote the development of China's commercial banks. However, interest rate liberalization has also brought many new challenges. Only by adjusting at the fastest speed can China's commercial banks deal with the opportunities and challenges brought by it.

\section{References}

1. Ba S, Zhong W. Influencing Factors of Commercial Bank Net Interest Margins: A Literature Review. Journal of Hubei University of Economics 2017; 15(4): 60 - 66.

2. Fang S. Study on the influencing factors of net interest margin of Chinese commercial banks in the process of interest rate liberalization [Master's thesis] (in Chinese). Xiangtan University; 2016. p. 55.

3. Han Z, Wang Y. Study on the influencing factors of interest rate spread of commercial banks under the background of interest rate liberalization (in Chinese). Journal of Capital University of Economics and Business 2017; 19(1): $18-24$.

4. Jiang B. International Finance New Edition. 3rd ed. Fudan University Press. 2001.

5. Li K, Yang Y. Interest rate liberalization and China's small and medium-sized commercial banks: opportunities, challenges and enlightenment (in Chinese). Journal of Finance and Economics 2013; (1): 47 - 51.

6. Sun J. Study on the impact of interest rate liberalization on Chinese commercial banks - based on the perspective of interest rate change [Master's thesis] (in Chinese). Liaoning University; 2018.

7. Xie D. Study on the influencing factors of commercial bank net interest margin in the process of interest rate liberalization [Master's thesis] (in Chinese). Southwestern University of Finance and Economics; 2015.

8. Xu X. Opportunities and challenges faced by commercial banks under interest rate liberalization (in Chinese). Market Weekly 2016.

9. Zhang Q, Wang S. The internationalization of RMB brings opportunities and challenges to China's commercial banks (in Chinese). New Finance 2010; (10): 56 - 59

10. Zou J. Study on the impact of interest rate liberalization on small and medium-sized commercial banks and countermeasures (in Chinese). Journal of Huaihua University 2015; 34(02): 24 - 27. 